\title{
FEASIBILITY OF A WATER MARKET IN COLOMBIA
}

\author{
J.A.VASQUEZ \\ Business School, Eafit University, Colombia.
}

\begin{abstract}
Over the last 20 years there have been advances in changes to the legislation surrounding water resource management in several Latin American countries, with the objective of improving the government's role in water protection through more active participation on the part of the private sector in the provision of utilities, essentially through the use of a market-based mechanism. The main objective of this paper was to analyse the feasibility of creating a water market in Colombia, provided that the three necessary conditions for the commercialisation of this resource exist: property rights distribution, public information of demand and supply of water rights and the physical and legal feasibility of executing this exchange.

Keywords: environmental regulation, natural resources market, property rights, water, water concession or license.
\end{abstract}

\section{INTRODUCTION}

Water is a natural resource that is fundamental to the development of social and industrial activity in any country, and is therefore a determinant in the sustainability of the economy and the society at large. According to Colombian legislation, environmental authorities are responsible for the management of water resources. This management is significantly difficult and costly in economic and environmental terms because of the economic investments required as well as the vast lack of knowledge about the water resources that the country possesses. Now that the entities managing the country's natural resources do not have the technical, economic and infrastructural capability, they cannot meet their objectives in a satisfactory manner. This has led to a rapid deterioration of natural resources and in particular, water resources, which can produce unpredictable negative consequences for the country's development and society's well-being. The situation in Colombia does not differ much from that of some Latin American countries at present [1]. In many countries, this rapid deterioration of resources has created an interest in the reformation of environmental regulation, via the search for improved use, distribution and access to water resources. This could be accomplished through the more active participation of the private sector in the provision of utilities related to the supply of water. To achieve this, there is the proposed use of a market-based mechanism, negotiable contamination permits and renewable natural resource markets, among other things. The approach of natural resource preservation through a market system, stems from the belief that markets can preserve resources if everyone who uses them assumes their recovery cost, i.e. the cost of their protection and improvement [2].

This paper aims to present an analysis of the feasibility of creating a water market in Colombia as a mechanism for the regulation of water resources. The analysis will contribute legal elements to support the discussion on the possible positive and negative consequences of this market for society. The paper is organised in the following way: the second part presents a brief background of the issues in South America and in Colombia. The third part tackles the issue of a market-based mechanism, and water markets in particular. The fourth part analyses the feasibility of implementing a water market in Colombia, provided the physical and legal feasibility to execute the trade of this resource through a market exist. Finally, the paper presents conclusions on the technical and legal feasibility to create a water market in Colombia.

(C) 2008 WIT Press, www.witpress.com

ISSN: 1743-7601 (paper format), ISSN: 1743-761X (online), http://journals.witpress.com

DOI: 10.2495/SDP-V3-N4-394-400 


\section{BACKGROUND}

In the current capitalist system, natural resource markets initially try to resolve two problems: resource distribution and the economic cost of sustainability which implies protection and improvement, such as purification, rather than just guarantee the population of a country or region access to water. Therefore, the market will distribute resources to those who are economically capable of paying for them. This distribution through markets could generate significant negative consequences for developing countries (of which Latin America forms part), because it refers to a population whose level of income per capita is among the lowest in the world. In accordance with Panayotou [3], laissez-faire markets could efficiently distribute resources for different uses such as industrial, commercial, domestic, etc. However, over time the problem for water markets will not lie exclusively in the matter of efficiently resolving distribution issues, but in the fulfilment of human needs, which is fundamental to man's survival.

In developing countries, 1.2 billion people live below the poverty line, with incomes estimated at 1 dollar per day. Water-related preventable diseases claim the lives of five million people every year, four million of which are children. In the world today, it is estimated that 1.2 billion people lack access to safe water supply and 2.4 billion do not have access to adequate sanitation, so the population's access to water and the sustainability of the resource jeopardise both the quality of life and in particular, a guaranteed food supply for the population [1].

The former becomes more worrying considering the fact that Latin America has not caught on to the wave of water resources privatisation and the use of other market mechanisms on water resources management that has swept other parts of the world. There has been a propitious opportunity for the governments of countries like Chile, Bolivia, Uruguay and Argentina to move forward with attempts to use a market-based mechanism such as water resources privatisation for water resources management but with unsatisfactory results. So, in the countries which favour liberalisation processes and the participation of private agents in the supply of water, the price of water has increased [1] and improvement in terms of access to the resource, which relates to water markets, has not achieved the expected results. Apart from this, difficulties facing the Chilean government, the existence of water markets [4], as well as the content of a Colombian Constitutional Court ruling, in which it was determined that distribution of property rights for the country's renewable resources is possible, all indicate the urgency for a discussion on the feasibility of a water market in Colombia.

\subsection{The condition of water resources in Colombia}

Public management of water resources has placed the country in a situation characterised by the following conditions: the overexploitation of the resource through urbanisation and industrialisation in general; the absence of resource prices that cover the negative externalities generated from its use; the high social cost of environmental contamination caused by use of this resource, which is paid by everyone and not just those who cause it; the ever increasing economic cost of protection, improvement and preservation of the resource, given its rapid deterioration; and the maintenance of a subsidy system with regard to usage rates, given that they do not take into account the true cost of maintaining this resource [5].

\section{MARKET-BASED MECHANISM}

In the light of the need to control society's behaviour with regard to the use of natural resources, the international community has developed various market-based mechanisms which have in some way provided a solution to the problem. Among these economic tools, we have renewable natural resource markets. The following will present the water market and some of the characteristics relevant to its operation. 


\subsection{Water markets}

In a water market, water is traded at a price determined by the forces of supply and demand in a free market, and by some type of property right to its use, whether for a specific time frame as in the case of leasing or in perpetuity as in the case of a sale [6]. The interaction between buyers and sellers of rights is what constitutes a water market. The market is the institution that will facilitate the trading of water rights between buyers and sellers.

\subsection{Necessary conditions for trade}

According to Young and Haveman [6], in a water market, as in any other market which endeavours to function efficiently, certain basic conditions must exist to permit this trade. These are, well defined, enforceable and transferable property rights, public information about supply and demand of water rights and the physical and legal feasibility to execute this exchange.

\subsection{Property rights}

Government defines and limits property rights and the obligations to the rest of the society of those who maintain legal access to the resource, ensuring that they use a specific quantity of water. Inadequately defined rights will obstruct the establishment of the market since it will appear to buyers and sellers as an unreliable transfer mechanism of the resource. For market players to estimate the value of a water right there must be a means of establishing foreseen expectations of the costs and benefits linked to the possession and transfer of the right. Otherwise, the market will cease to operate efficiently due to its lack of investment incentives.

\subsection{Public information about supply and demand of water rights}

Public information that identifies buyers, sellers and intermediaries of water rights is a necessary part of a water market. In this regard, Perry et al. [7] suggest the presence of a property rights public registry which market players can access. In the same way, it is important to provide information on the legal procedures involved in signing purchase contracts, sales contracts and any other type of transaction.

\subsection{Physical and legal feasibility to execute the exchange}

There must exist in a water market, first the physical presence of the resource which gauges the hydrological risk associated with the quantity of water in the source. By hydrological studies about the rain in a basin, it is possible to estimate the hydrological risk, that is, determine the probability associated with the quantity of water that is available at the source at a particular time; and secondly the availability of adequate technology to extract the water from the rivers and a medium of transportation such as infrastructure that ensures safe mobility of the resource (pipelines to transport the water). Adequate technology for extracting, transporting and distributing water is one that does not generate negative environmental impact on the water source, and environment.

Market regulatory framework is required and there must be clear guidelines which guarantee, protect and permit transactions among agents. The market's continuity is dependent on the existence of transfer standards which are not only clearly understood by all the agents, but sensibly applied. This will allow potential players to make sound decisions based on the market and also forecast future business. 


\subsection{Types of transactions}

The transfer of water rights can take many forms. The following are the types of transactions that Young and Haveman [6] identify in a water market. A sale is the permanent transfer of a right, including all the benefits, costs, risks and obligations associated with it. A lease contract refers to the sale of water but not the sale of rights. In this case, the leaser retains the title to the water right and regains the resource at the end of the lease. An option contract is a long-term lease agreement, and in some instances a sale when there is a particular eventuality (drought) and it is usually used to transfer water from irrigation agriculture to non-agricultural users during periods of scarcity.

\section{FEASIBILITY OF A WATER MARKET IN COLOMBIA}

To analyse the feasibility of a water market in Colombia, the following three conditions must be considered.

\subsection{Property rights}

To operate a water market it is essential that the property rights related to the resource under consideration be well defined. In this regard, the 1998 Colombian Constitutional Court ruling allowed the exploitation of renewable natural resources such as water, through the granting of property rights, which enables the creation of a market for these resources.

\subsection{Public information on the demand and supply of water rights}

Despite the aforementioned ruling, Colombia still does not have available public information about the supply and demand of water rights and this situation creates an obstacle in the creation of a water resource market.

\subsection{Physical and legal feasibility of executing this exchange}

In terms of water resource regulation, a water license or water concession is the most effective mechanism for government to control and protect this resource, and is therefore the most useful in analysing the feasibility of a water market. A water license is a form of authorisation which the government grants to an individual to use water from public, artificial (rivers, lakes) and underground sources for a specific period of time and for domestic, industrial, commercial and recreational activities among others. Once the concession term or period has expired, it is necessary to reapply to the appropriate authority to regain rights to the resource. Water licenses are granted for exclusive use, for example, industrial, irrigation, recreation, etc. and this cannot be modified without authorisation from the environmental entity that granted the right. Moreover, this license cannot be transferred between users without prior approval from authorities. This hinders the process of changing users.

Water licenses or concessions are regulated by Act 1541 of 1978 [8] and although the Act has been in effect for almost 30 years, the level of illegal activity regarding water use is quite high throughout Colombian territory, especially in rural remote areas. In the cities, however, public water supply, generally speaking, is legal. This creates a barrier to the successful operation of a water market because of considerable uncertainty with regard to regulation compliance. This is unappealing to potential water market investors.

Given that water licenses are issued by an environmental authority, license holders do not possess the right to construct water supply networks to transport and distribute water on private property. 
If the particular use of the resource requires use of private territory, transportation of the resource is hindered and the water right becomes ineffective. Despite this, the resource is widely available in Colombia and this could be advantageous to the transportation and distribution of water, as well as the negotiated transfer of water rights in a water market.

Pertaining to the appropriate means and technology necessary to ensure the safe distribution of water, Colombia has the technical capacity for construction of hydraulic structures, i.e. there exists trained human capital. Resource distribution requires a public water network in the country's main rural areas for agricultural exploitation. In these areas armed conflict and poverty affect most of the population. According to 2006 data from the National Department of Planning, poverty affects up to $71.5 \%$ of the population, of which $41.5 \%$ of the inhabitants are beggars [9]. For this reason private or public investment in the exploitation of land and its resources is very difficult and expensive for the country.

The creation of a water market therefore requires an extensive water distribution network which takes advantage of the existence of the resource in the country. This requires large-scale investment on the part of a water distributor, government or a private individual who constructs networks in the country.

\subsection{Water markets and Act 1541 of 1978}

Although in accordance with the Colombian Constitutional Court ruling, it is possible to establish a water market, Act 1541 of 1978 contains certain conditions and characteristics concerning the award of water licenses which obstruct the establishment of such markets.

To receive a water license, the interested party must state beforehand his or her intended use for the resource, for example, human consumption, irrigation, forestry, energy generation or industrial among others. This is due to the fact that the license is granted only for an exclusive use which can only be modified by the environmental authority. Given that the establishment of a water market presently requires complete freedom for the resource owner to conduct transactions, the Act regulating these licenses requires modification so that resource uses can be changed without authorisation. Otherwise, a water market cannot be established because complete mobility of resources based on market indicators will not be guaranteed.

According to Act 1541 of 1978, the issuance of all water licenses is subject to the possession of a waste water disposal permit. This permit is issued by an environmental authority. If an applicant for a water license does not have a waste water disposal permit, then the license is not granted. This permit presents another obstacle in the transfer of water rights because it means that whoever possesses water property rights must also possess a waste water disposal permit in order to obtain a water license [10].

The Act also dictates that water licenses are granted based on the priority level of the economic activity for which the resource will be used. For example, water used for energy generation such as hydroelectricity takes priority over water used for recreational purposes. This means that based on the intended use of the resource, one company can have marketing power over others.

The environmental authority has the right to generally modify all water licenses granted in the interest of public use and social interest. There is therefore no full guarantee of retaining the water license granted since the authorities have the means of modifying the licenses when they consider it necessary.

Since there is a limited period to take advantage of the water license, license holders may encounter difficulty in finding potential business partners when the license expiry period approaches. There is also a risk attached to any type of negotiation with this business. 
The establishment of a water market requires complete flexibility for the license holder in selling and buying the resource. In this regard, Act 1541 of 1978 considers the possibility of total or partial transfer of the license on the part of the dealer having received prior authorisation from the environmental entity. The Act also considers the denial of transfer for reasons of public use or social interest.

\subsection{Prices and market indicators}

In Colombia, the Ministry of Environment, Housing and Regional Development, which is at the top of the environmental authorities' hierarchy, has not fully estimated the economic value of water resources in the country and therefore the regulations created have had severe problems in their application and even now there are significant difficulties with their use in the country. Without clear resource prices, investing in the market becomes less feasible since it is almost impossible to forecast return on investment.

It is important to note that although the Colombian Constitutional Court ruling opens doors for the distribution of property rights for renewable natural resources in the country as is the case with water, it does not solve the problem of creating a water market because it is a significantly complex subject in the light of the environmental regulation in force in Colombia. At the time of writing this paper, the Ministry of Environment has presented a project on Water Law which will allow the creation of a water market in the country. However, this is no simple task from a legal standpoint and much less from a political, economic and social standpoint (public order), given that these aspects can be much more relevant and complex than the legal context.

Although the change in Act 1541 of 1978 could facilitate the creation of a water market, it could bring about significant negative effects on the community, such as:

1. Loss of priority for domestic use of water. There would be changes in the level of priority as regards water use for domestic consumption in the face of other uses, such as industrial, agricultural, energy generation and recreational. This could create water shortages for communities, in favour of industries, and this could affect health and general social well-being.

2. Deterioration of the economy. If due to high water prices, the population has less access to water resources, this could have direct negative effects on the health of communities and indirect effects on the economy, due to loss of productivity as a consequence of the community's deteriorating health.

3. By treating water as a market, industries and persons with greater economic power would have an advantage in accessing water resources, in comparison with the poorer population. Under these conditions, water would be available to those who possess greater economic capacity to buy it, instead of the people who need it to survive. This problem is even more serious in Colombia considering that the poverty level within the population is $80 \%$. Thus, a population with fewer possibilities of accessing water resources is expected to have greater health problems. This would imply high economic (investment) costs which the government would have to assume, in order to adopt measures to protect public health.

Generally speaking, the population would have fewer opportunities to access water for domestic use, and would be at a greater risk for contracting diseases associated with the lack of drinking water and in turn would face difficulties surviving.

\section{CONCLUSION}

Although the creation of a water market in Colombia seems possible in the light of the Colombian Constitutional Court ruling, the reality is that there remain certain legal considerations that will 
make the materialisation of water rights transfers notably difficult due to various operational issues within the market. It is true that the ruling opens doors to a renewable natural resources market in the country given that it endorses the allocation of property rights to these resources, but this is not sufficient for the creation, operation and development of such a market.

The creation of a water market in Colombia through the use of water licenses or concession requires substantial amendments to Act 1541 of 1978.

The lack of infrastructure for water transportation between rural areas demands considerable infrastructural development, without which the creation and operation of a water market will be severely hindered.

As indicated above, a water market in Colombia could generate negative effects on the population and the development of the country, as has occurred in other Latin American countries.

\section{REFERENCES}

[1] Christiansen, J. \& Hall R., Privatización, naturaleza en venta: impactos de la privatización del agua y de la biodiversidad. Amigos de la Tierra, 107, pp. 10-25, 2005.

[2] CEPAL, División de Recursos naturales y Energía, Mercados de derechos de agua: Entorno legal, pp. 1-19, 1995.

[3] Panayotou, T., Economics, environment and development, Development Discussion Paper 259, 1987.

[4] Larraín, S., El agua en Chile: entre los derechos humanos y las reglas del mercado, en Polis, Revista de la Universidad Bolivariana, volumen 5, número 14, Santiago, Chile, pp. 9-11, 2006.

[5] Economía Ambiental, Departamento Nacional de Planeación, volumen XXVII/número 2/ abril-junio de 1996.

[6] Young, R. \& Haveman, R.H., Economics of waters resources: a survey. Handbook of Natural Resources and Energy Economics, eds A.V. Kneese \& J.L. Sweeney, Elsevier: New York, pp. 465-529, 1985.

[7] Perry, C., Rock, M. \& Seckler, D., Water as an Economic Good: A Solution or a Problem? Research Report 14, International Irrigation Management Institute: Colombo, Sri Lanka, 1997.

[8] Decreto 1541 de 1978 del Ministerio de Agricultura de Colombia.

[9] Martinez, H., Agricultura-Colombia: La despensa se agota. http://ipsnoticias.net/nota.asp. December 5, 2007.

[10] Decreto 1594 de 1984 del Ministerio de Agricultura de Colombia. 